\title{
Geological and site specific factors influencing earthquake hazard assessment for New Brunswick, Canada
}

\author{
B.E. BROSTER* AND K.B.S. BURKE \\ Quaternary and Environmental Studies Group, Department of Geology, \\ University of New Brunswick, Fredericton E3B 5A3, Canada \\ *Corresponding author $<$ mail: broster@unb.ca $>$
}

Date received: 12 August 2010 g Date accepted 11 April 2011

\begin{abstract}
Seismic hazard studies by Earthquakes Canada place most of New Brunswick in the moderate part of the hazard range. Limitations are identified with the documented earthquake database suggesting that revisions are necessary for location and magnitude of some of the known historical earthquakes. In addition, the disturbance from a given event magnitude can be modified by local geological conditions and site specific factors. This is particularly true for New Brunswick, where many of the communities were settled along river valleys and coastal areas, which are underlain by thick deposits of glacial and alluvial sediments that can amplify ground motion. The historical documentation and paleoseismic studies that identify seismic-generated disturbances are reviewed in this paper. Ground motion from both moderate $\left(4 \mathrm{M}_{N}\right)$ local and large $\left(>5 \mathrm{M}_{N}\right)$ regional earthquakes represents a hazard at some locations and particularly those sites adjacent to steep slopes or sites underlain by thick surficial deposits. Amplification of ground motion would be expected at sites overlying low shear wave velocity zones typical of alluvial sediments. This may explain the larger shaking effects experienced in the downtown area of Fredericton from distant earthquakes. Alteration of springs, rivers and groundwater supplies has happened as a result of earthquakes, although few effects remain permanent. Reports of earthquake-generated tsunamis and lake seiches are rare for New Brunswick. Earthquake-induced rock falls occurred along some rock slopes during moderate earthquakes in 1855 and 1937, and a landslide occurred in marine sediments possibly triggered by a minor unrecorded local tremor in 1977 . This study identifies the need for future paleoseismic research and microzonation studies for the major communities within the province.
\end{abstract}

\section{RÉSUMÉ}

Des études de l'aléa sismique réalisées par Séismes Canada situent la majeure partie du Nouveau-Brunswick au niveau moyen de l'échelle de l'aléa. La base de données sismologiques documentées fait part de restrictions laissant supposer la nécessité de révisions de l'emplacement et de la magnitude de certains des tremblements de terre passés connus. De plus, les secousses dues à la magnitude d'un séisme donné peuvent être modifiées par les conditions géologiques locales et par des facteurs propres à l'emplacement. C'est particulièrement le cas au Nouveau-Brunswick où de nombreuses localités se sont implantées le long de vallées fluviales et de secteurs côtiers qui reposent sur des dépôts épais de sédiments glaciaires et alluvionnaires pouvant amplifier les mouvements du sol. Cet article passe en revue la documentation historique et les études paléosismiques qui définissent les secousses sismiques. Les mouvements du sol que produisent les tremblements de terre régionaux importants $\left(>5 \mathrm{M}_{N}\right)$ et locaux moyens $\left(4 \mathrm{M}_{N}\right)$ représentent un aléa en certains endroits, particulièrement à proximité des pentes abruptes ou des secteurs reposant sur des dépôts superficiels épais. Une amplification des mouvements du sol peut être anticipée dans les secteurs recouvrant des zones de faible vitesse d'ondes transversales typiques des sédiments alluvionnaires. Une telle situation pourrait expliquer les secousses plus marquées vécues dans le centre-ville de Fredericton par suite de tremblements de terre éloignés. Certains séismes ont modifié des ruisseaux, des rivières et des réserves d'eaux souterraines, mais de tels effets sont rarement permanents. Il est rare qu'on signale des tsunamis et des seiches sur des lacs dus à des tremblements de terre au Nouveau-Brunswick. Des éboulements provoqués par des séismes sont survenus le long de certaines pentes rocheuses au cours de tremblements de terre moyens en 1855 et en 1937, et un glissement de terrain possiblement déclenché par une faible secousse sismique locale non enregistrée en 1977 s'est produit dans des sédiments marins. L'étude démontre la nécessité d'études de microzonation et de recherches paléosismiques futures visant les principales localités de la province.

[Traduit par la redaction] 


\section{INTRODUCTION}

The procedures for the determination of earthquake hazard are well established and consist of two major methods: (1) probabilistic, based on the earthquake record and (2) deterministic, where seismicity can be related to specific faults (Reiter 1990). A prime requirement is the compilation of earthquakes recorded by seismograph networks, extended, if possible, by a catologue of historical earthquakes. Probabilities of re-occurrence of earthquake magnitudes can then be calculated based on this information. Paleoseismic studies will often add essential information and extend the time interval over which the hazard is assessed by utilizing information from a variety of disciplines that could include Quaternary geology, geomorphology, archaeology and structural geology (e.g., Broster et al. 1993; Tuttle et al. 1996). If seismogenic faults do not occur in the region, then source zones, within which earthquake characteristics are similar, need to be identified.

Earthquakes Canada is responsible for the evaluation of regional seismic hazard in different parts of Canada. Seismic hazard maps have been prepared by analyses of the past earthquake records and from information on a region's tectonic and geological structure. These maps show the largest ground motion that is expected to occur in an area for a given probability

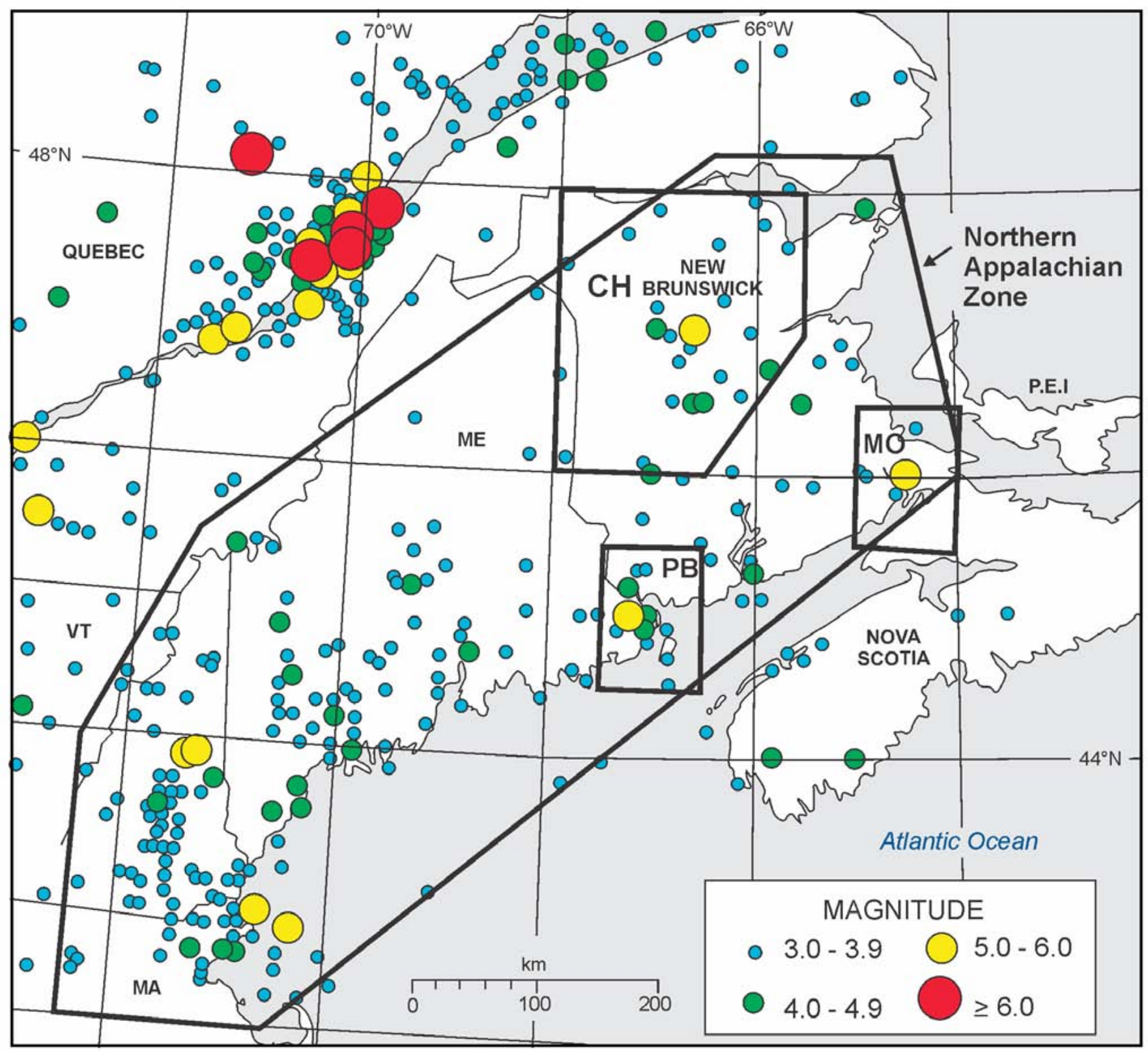

$\mathrm{CH}$ - Central Highlands sub-zone PB - Passamaquoddy Bay sub-zone $\mathrm{MO}$ - Moncton sub-zone

Fig. 1. Map of earthquake sub-zones in New Brunswick after Burke (2004). 
level. The relative seismic hazard across Canada for one- to twostory structures places most of New Brunswick in the moderate part of the hazard range (Natural Resources of Canada 2010a).

Moderate hazard regions represent a 5 to $15 \%$ chance that significant damage could occur every 50 years. Site specific values can be determined using a menu on the Earthquakes Canada web site (Natural Resources of Canada 2010b).

Earthquakes Canada has identified earthquake zones likely to experience similar levels of activity in Canada. Most of New Brunswick lies within the Northern Appalachian (earthquake) Zone (Natural Resources of Canada 2010c), which extends from Nova Scotia south into the New England states. Burke (2004) has identified three areas of enhanced activity in New Brunswick; the Central Highlands, Moncton, and Passamaquoddy Bay subzones (Fig. 1). Halchuk et al. (2004) calculated maximum likelihood estimates of probability for these subzones using the method of Weichert (1980). This study showed that the activity rate in the Central Highlands subzone is higher by a factor of at least 2, and in the Passamaquoddy Bay subzone the activity rate is higher by a factor of 2 to 3 , compared to the Northern Appalachian Zone. In contrast, the activity rate in the Moncton subzone, in spite of the magnitude 5.4 earthquake of 1855 , was only about a half of that in the Northern Appalachian Zone (Halchuk et al. 2004). It is likely that the sampling period was too short for reliable estimates to be made for this latter subzone.

Although it may appear that the seismic hazard for New Brunswick is well defined by the above probabilistic studies, there are geological and site specific factors that may influence the hazards from earthquakes. For example, the deformation resulting from earthquake can usually be related to the magnitude and distance to the epicentre of an earthquake. Fault length and vertical displacement of bedrock are often measured and attributed to the size of the seismic event (i.e., Reiter 1990). However, where bedrock is buried, the intensity of the event may also be reflected as deformation structures in overlaying deposits of fine-grained sediments. Bolt (1995, p. 165 ) reports that during the $1977 \mathrm{M}_{\mathrm{s}} 7.2$ earthquake in Romania, sand boils occurred along the Danube River at a distance of $400 \mathrm{~km}$ from the epicentre. Deformation structures in delta sediments examined at Economy Point, Nova Scotia (Broster and MacDougall, 1997) on the north shore of the Minas Basin were attributed to the 1855 (M 5+) earthquake at Moncton, New Brunswick, $100 \mathrm{~km}$ to the west. Unstable slopes in landslide prone areas can be triggered to fail and endanger people and property. In addition, many communities are built on thick deposits of alluvial or glacial deposits, which enhance the effects of low frequency seismic waves. In some areas, the configuration of deep river valleys focus and increase the amplitudes of arriving waves, particularly when underlain by fine-grained sediments. It is to be expected that earthquake shaking will therefore be modified by local geological conditions across the province. Such phenomena are recorded in the descriptions of historical New Brunswick earthquakes (e.g., Burke 2009) and identified for the pre-historical period from two paleoseismic studies. This paper will describe some of the reported effects of historical and paleoseismic events documented at sites across New Brunswick and show why caution must always be used in assessing the hazards from earthquakes.

\section{EARTHQUAKE HAZARD ASSESSMENT}

\section{Instrumental observation of New Brunswick earthquakes}

The magnitude 5.4 earthquake on July 2, 1922 is the first New Brunswick earthquake recorded by seismographs, although the stations were outside the province (Humphreys 1922a, 1922b). No instrumentally determined magnitude was reported for this latter event. The first recorded earthquakes in the province for which instrumentally calculated magnitudes were reported occurred on January 4, 1930 and September 30, 1937 , for which a $M_{L} s$ of 4.6 and 5.0 are listed respectively by Smith (1966). Because Smith did not have a correct epicentre for this event, the magnitude for the 1937 earthquake was recalculated to be an $\mathrm{M}_{\mathrm{N}}=4.4$ by Burke (2009).

However, it was not until the 1960 s that a network of seismographs was available in eastern Canada to allow the recording of earthquakes with magnitudes as low as 2 to 3 in the province. For the period 1970 to 1982, a single vertical component station (UNB) was operated for the Geophysical Division of the Earth Physics Branch at the University of New Brunswick in Fredericton. After the magnitude 5.7 Miramichi earthquake on January 9, 1982, seismometers were installed in the province at Edmundston (EBN), Caledonia Mountain (LNM), about

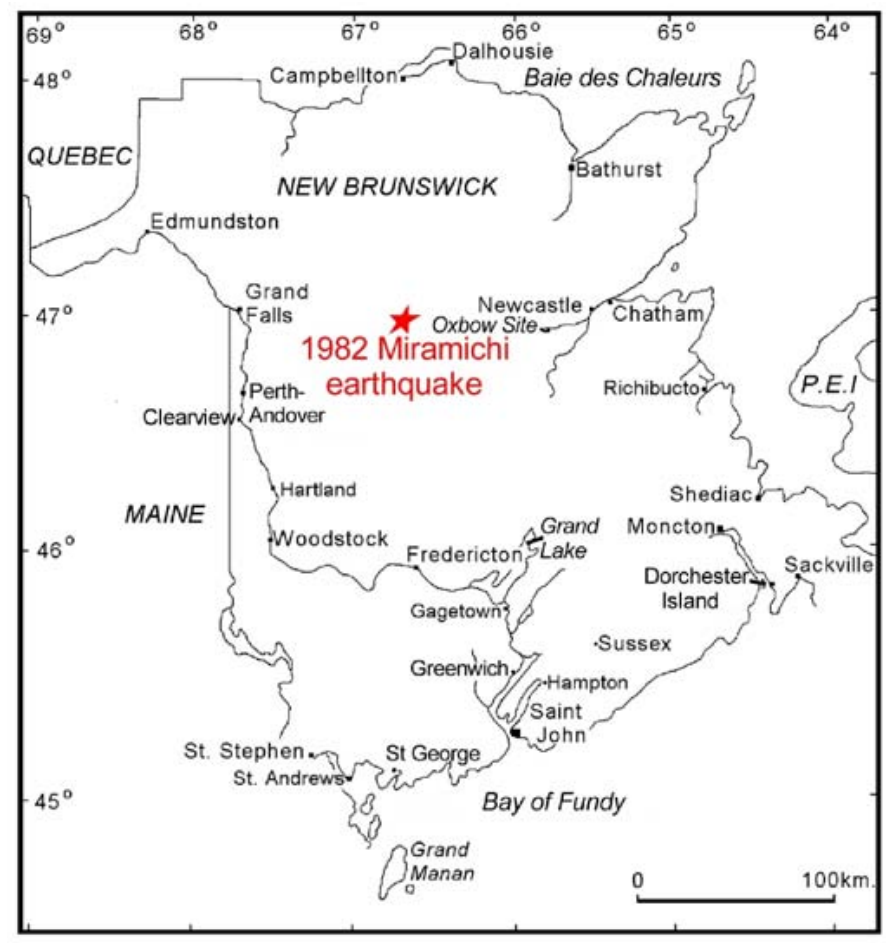

Fig. 2. Locations of communities discussed in text and site (star) of 1982 earthquake and aftershocks. 
$40 \mathrm{~km}$, south of Moncton, McKendrick Lake (KLN), about 20 $\mathrm{km}$ southeast of the Miramichi earthquake epicentre and St. George (GGN). These seismometers formed part of the Eastern Canada Telemetered Network(ECTN) from 1982 until the early 1990s. Today, only seismometer installations at Caledonia Mountain and St. George remain within the province (Fig. 2). These latter stations are now broad band, three component stations, whose traces can be accessed on the Internet (Natural Resources of Canada 2010b).

A database of Canadian earthquakes from 1985 onwards is available on the Earthquakes Canada website (Natural Resources of Canada 2010d). Lists and maps for selected regions can be obtained from this database by specifying latitudes and longitudes for a search area. A map showing the epicentres for earthquakes with magnitudes of 3 or greater in New Brunswick for the period 1985 to the present is shown in Fig. 3. Data prior

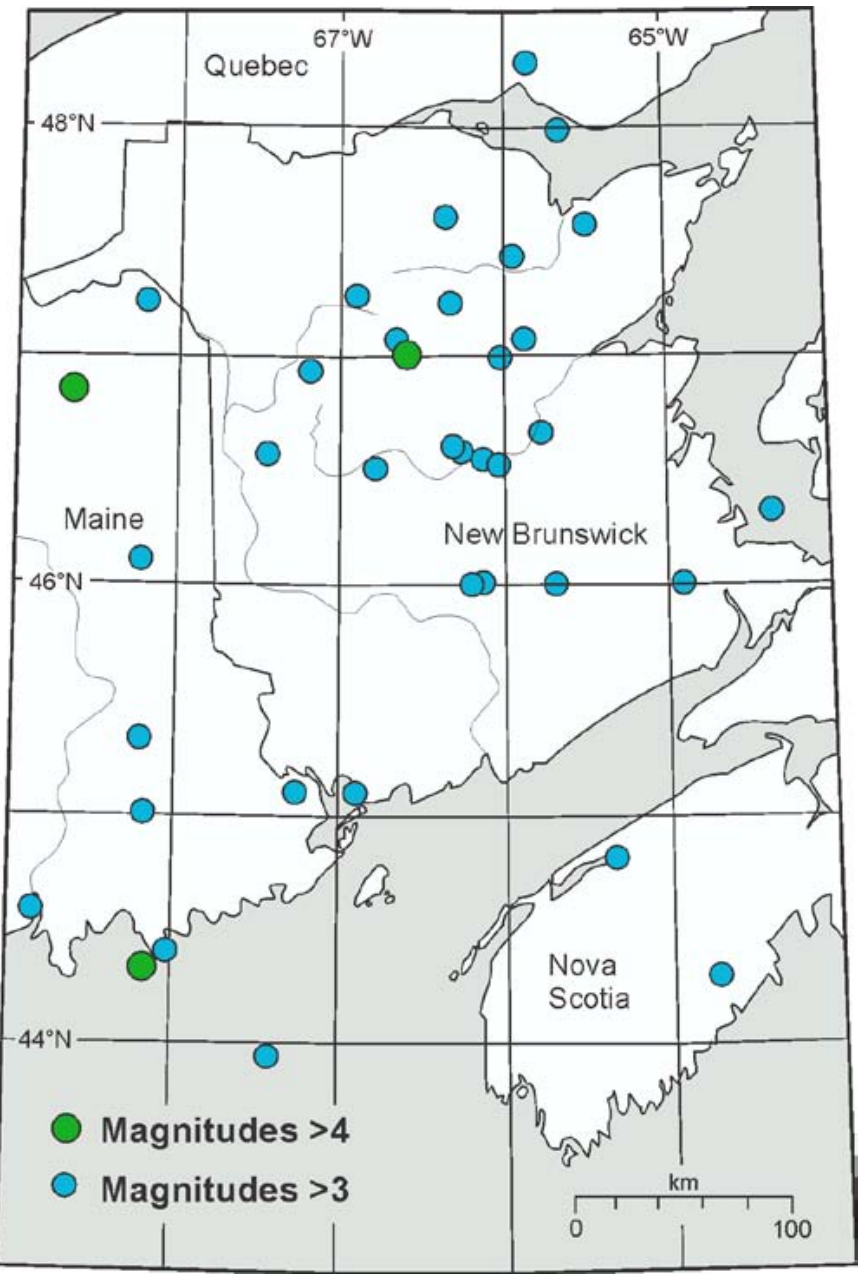

Fig. 3. Earthquake epicentre locations since 1985 of magnitude $>3$ for New Brunswick events, after Natural Resources of Canada (2010d). to 1985 is not included in this data base, which omits the 1982 sequence of earthquakes in the Miramichi area of the Central Highlands; the largest New Brunswick earthquake events recorded by seismographs. Epicentres for New Brunswick events for this period are plotted in Fig. 4. On both maps, the main events plot in the Central Highlands sub-zone (Burke 2004), where there has been a concentration of historical earthquakes (see below) and in the Passamaquoddy Bay and Moncton subzones (Fig. 1).

The 1982 Miramichi earthquake has been the only New Brunswick event to be subjected to a comprehensive study of geology and effects in the instrumentally recorded period. Basham and Adams (1984) report that the mainshock M 5.7 occurred January 9 and was followed by M 5.1 aftershock three and a half hours later and by an M 5.4 aftershock two and a half days later on January 11; field instruments recorded a

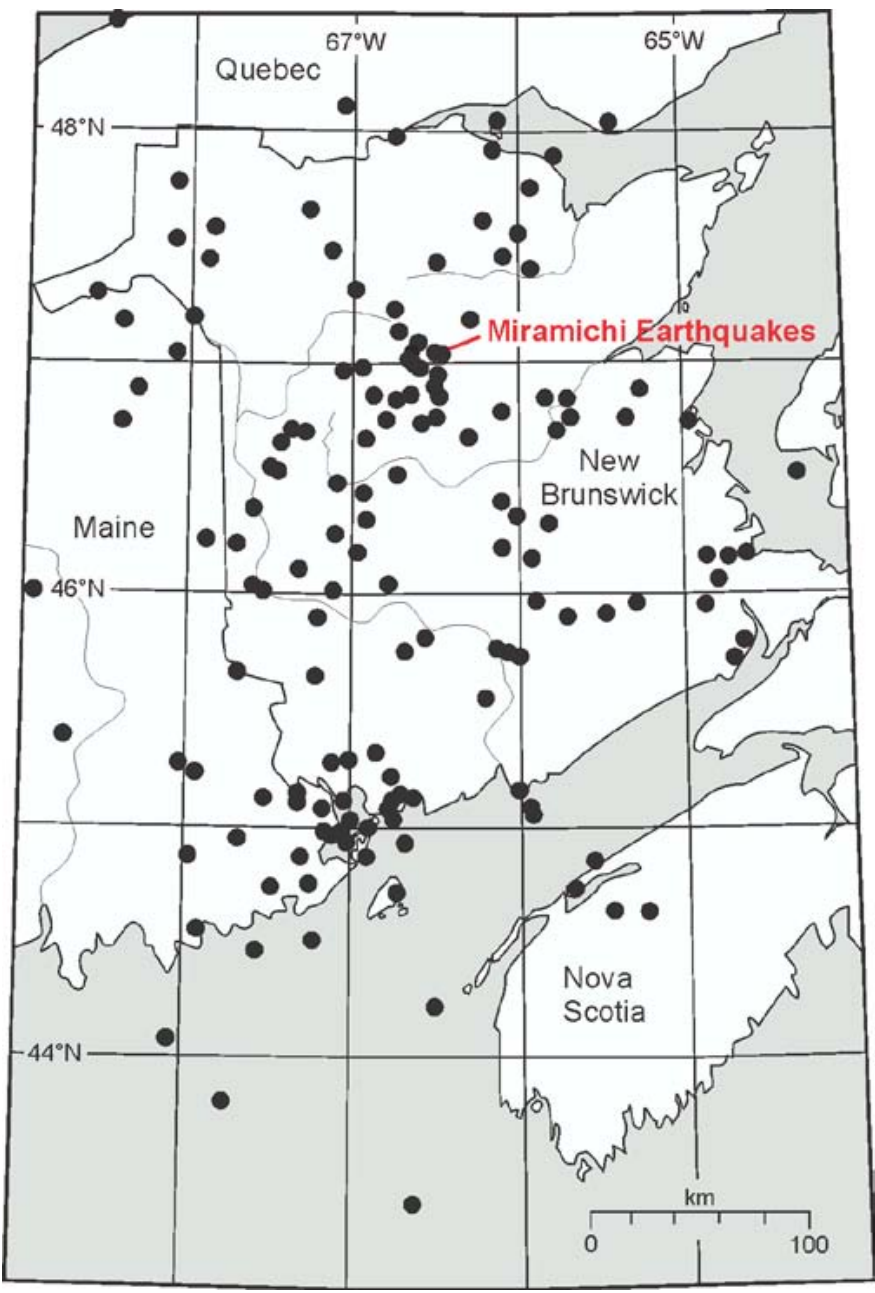

Fig. 4. Epicentres of earthquakes occurring between 1960 and 1984, after US Geological Survey (2010). Note the cluster of epicentres around the site of the January 9, 1982 Miramichi earthquake, and in the Passamaquoddy Bay and Moncton sub-regions (Fig. 1). 
further 237 after shocks in the 25 hour period between January 13-14th. Minor shocks (aftershocks?) associated with this system are still occurring to this date. Focal mechanism studies of the main event and larger aftershocks indicate a north trending conjugate $\mathrm{V}$ pattern of thrust faulting (e.g., Wetmiller et al. 1984; Basham and Kind 1986). On-site examinations by Basham and Adams (1984) of diorite outcrops close to the epicentre showed a few minor cracks, small-scale thrusting along a pre-existing joint (possibly glacitectonic), and a pop-up feature attributed to unloading during excavation, but no surface expression of a causative fault was found. In compressional tectonic settings, faults tend to develop as splays or blind thrusts and might not reach the surface (Wheeler and Johnston, 1992). Where fractures may have reached the surface the heavy vegetation and cover of glacial deposits would make small displacements extremely difficult to find. In these areas, sand blows and other seismic-generated disturbance of surface sediments may be the only evidence of a recent event. However, the Miramichi event occurred during conditions of frozen ground and was followed by $0.5 \mathrm{~m}$ of fresh snow before investigators could get to the site (Basham and Adams 1984, p. 117).

Fortunately, this 5.7 magnitude earthquake and large aftershocks were centred in a remote part of the Central Highlands. A full building damage survey was made after the event (Pernica and Maurenbrechen, 1982). Minor damage was reported in a few communities, at distances ranging between 60 to $115 \mathrm{kms}$ from the epicentre. Cracks in foundation walls, concrete block walls and plaster-lathe wood partitions were noted, although in many cases these tended to be caused by the widening of pre-existing cracks. Damage to stairwell walls was observed in a senior citizens' home in Bathurst (100 km from epicentre) and a hospital in Perth-Andover ( $85 \mathrm{~km}$ from epicentre). Gyproc panels were cracked in several retail stores, particularly in a one-storey store in Chatham ( $85 \mathrm{~km}$ from epicentre), where floor to ceiling cracks were developed or widened (see Fig. 2 for locations).

\section{Historical earthquakes (1811-1960)}

The historical seismicity of New Brunswick was investigated initially as part of a much larger study for the whole of eastern Canada by Smith $(1962,1966)$. Historical earthquakes of the region were included in a study of relationship to geological structure by Rast et al. (1979) and in a review of seismicity of the Maritime Provinces by Burke (1984). Leblanc and Burke (1985) studied the four largest known historical earthquakes in the Maine-New Brunswick region.

Earthquakes Canada maintains a comprehensive computer list of earthquakes as the National Earthquake Data Base (NEDB), formerly called the Canadian Earthquake Epicentre File (CEEF). Burke (2009) recently completed a study of historical earthquakes of New Brunswick for the years 1811-1960 and found evidence of 38 earthquakes, previously unlisted in NEDB. Most of the previously unlisted earthquakes were of relatively small magnitude and were only reported in one or two local newspapers, which may explain their absence from the NEDB. However, four moderate events in the Central Highlands were also identified by Burke (2009) that may have been missed previously because of their remote location far from larger communities. These moderate events were of magnitudes: 3.9 on March 16, 1863; 4.0 on December 18, 1903; 4.4 on March 20, 1911; and 3.9 on March 30, 1925.

The Modified Mercalli (MM) intensity scale is used to assign intensity levels from I to XII for an event (e.g., Reiter 1990; Bolt 1995). Table 1 lists the six largest earthquakes to have occurred during this period. The magnitudes and epicentres of the first five events are based upon the felt area and areas within the MM IV isoseismal. The epicentre and magnitude of the 1937 earthquake were determined by both instrumentally recorded data and felt data.

In the accounts of earthquakes in newspapers and other documentary sources, there is a wide range of reported effects for New Brunswick earthquakes, from simply 'felt' (MM II or

Table 1. Six largest historical New Brunswick earthquakes.

\begin{tabular}{ccccccl}
\hline Date & $\begin{array}{c}\text { Time (U.T.) } \\
\text { hr:min:sec }\end{array}$ & $\begin{array}{c}\text { Latitude } \\
{ }^{\circ} \mathrm{N}\end{array}$ & $\begin{array}{c}\text { Longitude } \\
{ }^{\circ} \mathrm{W}\end{array}$ & $\begin{array}{c}\text { Felt area } \\
\text { magnitude }^{1}\end{array}$ & $\begin{array}{c}\text { Isoseismal IV } \\
\text { magnitude }^{2}\end{array}$ & \multicolumn{1}{c}{ Sub-zone } \\
\hline May 22, 1817 & $07: 45$ & 45.0 & 67.2 & 4.6 & 5.4 & Passamaquoddy Bay \\
February 08, 1855 & $07: 03$ & 46.0 & 64.5 & 4.8 & 5.4 & Moncton region \\
October 22, 1869 & $09: 55$ & 46.5 & 67.0 & 5.3 & 6.0 & Central Highlands \\
March 21, 1904 & $06: 04$ & 45.0 & 67.2 & 5.3 & 6.0 & Passamaquoddy Bay \\
July 02, 1922 & $09: 22$ & 46.5 & 66.6 & 4.7 & 5.4 & Central Highlands \\
September 30,1937 & $07: 58: 10$ & 47.4 & 66.3 & $4.5^{*}$ & - & Central Highlands \\
\hline
\end{tabular}

Notes: ${ }^{1}$ Values determined by relationships between magnitude and felt area (Burke 2009). ${ }^{2}$ Values determined by relationships between magnitude and area within IV isoseismal (Burke 2009). * The Nuttli magnitude for this earthquake from seismograph records was 4.4. 
Table 2. Modified Mercalli (MM) intensity levels of larger New Brunswick earthquakes.

\begin{tabular}{lcccccccc}
\hline \multicolumn{1}{c}{ Community } & $\begin{array}{c}\text { Latitude } \\
{ }^{\circ} \mathrm{N}\end{array}$ & $\begin{array}{c}\text { Longitude } \\
{ }^{\circ} \mathrm{W}\end{array}$ & 1817 & 1855 & 1869 & 1904 & 1922 & 1937 \\
\hline Bathurst & 47.62 & 65.65 & & IV-V & IV & IV-V & V-VI & VI \\
Campbellton & 48.00 & 66.67 & & & & IV & IV & VI \\
Chatham & 47.03 & 65.46 & & IV & & V & IV-V & \\
Dalhousie & 48.06 & 66.38 & & & IV-V? & & & F \\
Edmundston & 47.37 & 68.33 & & & & NF & F & \\
Fredericton & 45.97 & 66.65 & III & IV-V & VI-VII & V-VI & IV-V & IV \\
Grand Falls & 46.92 & 67.75 & & & V-VI & & & \\
Hartland & 46.30 & 67.53 & & & & IV & IV-V & \\
Moncton & 46.10 & 64.78 & & VI-VII & & IV-V & IV & III-IV \\
Newcastle & 47.01 & 65.57 & & & V-VI & III & IV-V & \\
Sackville & 45.89 & 64.37 & & VI & IV & IV & III-IV & \\
Saint John & 45.27 & 66.05 & III-IV & IV-V & V-VI & V-VI & IV & \\
Shediac & 46.22 & 64.55 & & & IV-V & III & & NF \\
St. Andrews & 45.08 & 67.05 & V-VI & III-IV & IV-V & V-VI & & \\
St. George & 45.13 & 66.83 & & & III & V & & \\
St. Stephen & 45.19 & 67.28 & VI & & V & VI-VII & & IV \\
Sussex & 45.73 & 65.52 & & IV & & IV & IV & \\
Woodstock & 46.14 & 67.58 & & F & VI-VII & IV-V & IV & \\
\hline Not & & & & & & \\
\hline
\end{tabular}

Notes: Modified Mercalli intensity values assigned by Burke (2009). $\mathrm{F}=$ earthquake was felt. $\mathrm{NF}=$ earthquake was not felt.

III) to reports of 'chimneys collapsing and walls cracking'(MM VI-VII). The most common effects reported are the 'rattling of dishes or windows' and 'people were awaken' by the event (MM IV).

In Table 2, a summary of the Modified Mercalli intensity levels for those New Brunswick communities that reported having experienced the effects of these earthquakes is presented. As expected, most of the larger intensity values are listed where communities are close to the epicentre of an event. For example, intensity values of VI-VII have been assigned to St. Stephen for the 1817 and 1904 Passamaquoddy Bay earthquakes, because of chimney damage reported from there. Bricks falling from chimneys and cracking of plaster on walls in Moncton and nearby Hopewell, at the time of the 1855 earthquake, indicate these communities experienced intensities of VI and are in the epicentral region. Great rents in roadways and the river bank along the Petitcdiac River were observed for this latter event. Chimneys were knocked down or displaced in central New Brunswick communities at the time of the 1869 earthquake, which has been assigned a location in the Central Highlands (Burke 2009). Some springs appeared and others disappeared along the SW Miramichi River valley.

However, closeness to the epicentre is not required for damage to occur, particularly where local site conditions amplify the ground motion. This is the case for those places situated on unconsolidated deposits, as illustrated by the intensity values at Fredericton (discussed below), where early historical settlement had taken place on a river plain of thick alluvial sediments. Effects reported from there caused by quite distant earthquakes, such as those of 1855 and 1904, give intensity values that appear to be higher by one or two units than expected for the response at distances of 150 and $100 \mathrm{~km}$ respectively from the epicentres of these events.

\section{Large regional earthquakes}

Seven large regional earthquakes in the historical period from 1860 to 1960 have had noticeable effects in New Brunswick. Four of these earthquakes occurred in the Charlevoix region of Quebec, two in the state of New Hampshire in the USA and one occurred on the Grand Banks, in the Atlantic Ocean, south of Newfoundland (Fig. 5, Table 3). The distances from the epicentres of the Quebec earthquakes vary from about 160 $\mathrm{km}$ to Edmundston, in northwest New Brunswick, to about $500 \mathrm{~km}$ to Sackville, a community in the south east part of the province. Distances between the epicentral region of the New Hampshire earthquakes and New Brunswick vary between 360 $\mathrm{km}$ on the western boundary to $620 \mathrm{~km}$ on the eastern bound- 
ary of the province. The distances to the epicentre of the Grand Banks earthquake are $670 \mathrm{~km}$ from Sackville to about $1000 \mathrm{~km}$ from Edmundston respectively.

During these earthquakes, general shaking of buildings, rattling of dishes and awakening of people was reported in many communities throughout New Brunswick. Intensity levels reached IV-V in many places (Table 4). At some localities, effects associated with intensity levels as high as VI were reported, probably caused by local sites conditions. Such effects were observed in the Fredericton area of New Brunswick, during the1929 Grand Banks earthquake, approximately 830 $\mathrm{km}$ distant (Burke and Slauenwhite 1987). During that event, buildings in the city core, which were sited over thick deposits of glacimarine/glacilacustrine silt and clay, were seen to vibrate more intensely than surrounding areas sited on bedrock with thin glacial cover. For the 1925 Charlevoix earthquake, at places close to the New Brunswick - Quebec border, damage to buildings was reported. Unstable chimneys fell at Campbellton, partitions of walls were separated and glass broken at Dalhousie, and bricks were dislodged from the flue of a chimney in Clearview (Fig. 2). The most significant effect was damage to a chimney in a house in Grand Falls that caused a fire to start and raze the structure. Flow from artesian wells at Newcastle was immediately enhanced after the 1925 Quebec earthquake.

\section{Paleoseismic Investigations}

Deterministic studies include the examination of bedrock faults or overlying deformed sediments caused by underling or nearby fault-generated seismic activity (e.g., Reiter, 1990; Tuttle and Seeber, 1991; Clague et al. 1992; Doughty et al. 2010). Such studies can contribute valuable information and enable extrapolation of magnitude, timing and number of seismic occurrences beyond the historical record (e.g., Tuttle et al. 1996; Rajendran 2000). However, caution must be exercised when interpreting suspected tectonic deformation in glaciated areas, where similar-looking structures can be produced by a variety of mechanisms associated with glaciations (i.e., Broster 1991). Examples of two recent studies in New Brunswick are presented below with additional comments on other factors of concern for site assessment.

\section{Saint John, New Brunswick}

At Saint John, New Brunswick, glacial eroded bedrock with offset striae and grooves had been attributed to post-glacial seismic activity because of the reverse nature of the offsets (Matthew 1894). The offsets occur in Cambrian-Early Ordovician strata, exposed along a prominent valley in the central part of the city (Figs. 6a-c). The displaced glacial striae are most evident in argillite and sandstone of the King Square Formation, latest Middle to early Upper Cambrian in age (Tanoli and Pickerill 1988), which forms the eastern limb of a syncline at the Rock Street location examined by Matthew (1894) and also by Broster and Burke (1990). The orientation of the synclinal

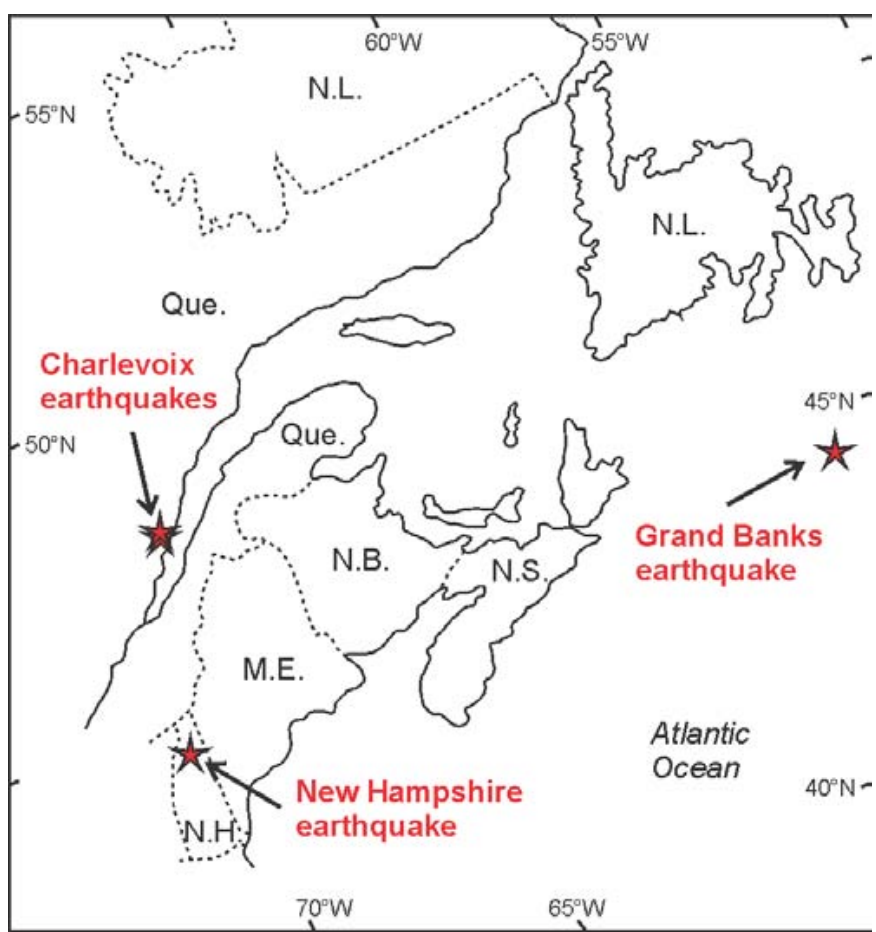

Fig. 5. Epicentres of large regional earthquakes occurring in the Charlevoix region $(1860,1870,1924,1925)$, Grand Banks area (1929), and New Hampshire (1940).

axis is approximately parallel to the valley and perpendicular to the orientation of striae.

The bedrock surface is polished, grooved and striated (Fig. $6 \mathrm{~b}, \mathrm{c}$ ). The striae are oriented southward (to $194^{\circ} \pm 10^{\circ}$ ) and attributed to the last direction of flow at the end of the Wisconsinan glaciation (Broster and Burke 1990). At the Rock Street location (Fig. 6a), Broster and Burke (1990) recorded 95 offset striae, most showing some reverse movement (northward) along bedding-controlled fractures that could be traced for only tens of metres; $24 \mathrm{~mm}$ was reported as the maximum single offset (Fig. 6b). Matthew (1894) concluded that the offsets at the Rock Street location represented in total $1.72 \mathrm{~m}$ of displacement, which would indicate a significant local earthquake if due to a single event. Broster and Burke (1990) observed that some reverse offsets were rounded by glacier overriding and likely contemporaneous with glaciation. They concluded that the displacements represented the response of multi-layered sedimentary rocks with anisotropic strengths, to differential rates of glaciation and unloading, resulting in differential and reverse displacement along bedding planes.

\section{Oxbow Settlement Site, Miramichi, New Brunswick}

Archaeological investigations at the Oxbow Settlement site, Miramichi area in northeastern New Brunswick (see Fig. 2 for location), exposed six deformed structures during excavations to a depth of $2.5 \mathrm{~m}$ into thinly stratified alluvial silt and sand. 
Table 3. Seven large regional earthquakes with noticeable effects in New Brunswick.

\begin{tabular}{lccccl}
\hline \multicolumn{1}{c}{ Date } & $\begin{array}{c}\text { Time (U.T.) } \\
\text { hr:min }\end{array}$ & $\begin{array}{c}\text { Latitude } \\
{ }^{\circ} \mathrm{N}\end{array}$ & $\begin{array}{c}\text { Longitude } \\
{ }^{\circ} \mathrm{W}\end{array}$ & Magnitude & \multicolumn{1}{c}{ Comments } \\
\hline October 17, 1860 & $11: 15$ & 47.50 & 70.10 & $6.0 \mathrm{ML}^{\mathrm{a}}$ & Charlevoix region, Que. \\
October 20, 1870 & $16: 30$ & 47.40 & 70.50 & $6.5 \mathrm{ML}^{\text {a }}$ & Charlevoix region, Que. \\
September 30, 1924 & $8: 54$ & 47.80 & 69.80 & $5.5 \mathrm{ML}^{\mathrm{a}}$ & Charlevoix region, Que. \\
March 01, 1925 & $2: 19$ & 47.80 & 69.80 & $6.5 \mathrm{ML}^{\mathrm{b}}$ & Charlevoix region, Que. \\
November 18, 1929 & $20: 32$ & 44.69 & 56.00 & $7.1 \mathrm{ML}^{\mathrm{c}}$ & Grand Banks, NL. \\
December 20, 1940 & $7: 27$ & 43.87 & 71.37 & $5.5 \mathrm{ML}^{\mathrm{d}}$ & New Hampshire, USA \\
December 24, 1940 & $13: 34$ & 43.91 & 71.28 & $5.5 \mathrm{ML}^{\mathrm{d}}$ & New Hampshire, USA \\
\hline
\end{tabular}

Note: Local magnitude scales have been retained in the above listing to allow an approximate comparison to be made between the sizes of the regional earthquakes. Moment magnitude values of $\mathrm{Mw}=6.2 \pm 0.2$ for the March 01, 1925 earthquake and $\mathrm{M}_{\mathrm{w}}=7.2 \pm 0.3$ for the November 18, 1929 have been determined by Bent (1992, 1995). ${ }^{\mathrm{a}}$ Lamontagne et al. (2007); ${ }^{\mathrm{b}}$ Bent (1992); ${ }^{\mathrm{c}}$ Bent (1995); ${ }^{\mathrm{d}}$ NEIC listing http://neic.usgs.gov/neis/epic/epic.html.

Table 4. Modified Mercalli (MM) intensity levels from larger regional earthquakes.

\begin{tabular}{|c|c|c|c|c|c|c|c|c|c|}
\hline \multirow[b]{2}{*}{ Community } & \multirow[b]{2}{*}{$\begin{array}{l}\text { Latitude } \\
{ }^{\circ} \mathrm{N}\end{array}$} & \multirow[b]{2}{*}{$\begin{array}{l}\text { Longitude } \\
{ }^{\circ} \mathrm{W}\end{array}$} & \multicolumn{4}{|c|}{ Quebec Earthquakes } & \multirow{2}{*}{$\begin{array}{c}\begin{array}{c}\text { Grand Banks } \\
\text { Earthquake }\end{array} \\
1929\end{array}$} & \multicolumn{2}{|c|}{$\begin{array}{c}\text { New Hampshire } \\
\text { Earthquakes }\end{array}$} \\
\hline & & & 1860 & 1870 & 1924 & 1925 & & $\begin{array}{c}\text { December } \\
20,1940\end{array}$ & $\begin{array}{c}\text { December } \\
24,1940\end{array}$ \\
\hline Bathurst & 47.62 & 65.65 & $\mathrm{~F}$ & IV & IV & IV-V & IV-V & & \\
\hline Campbellton & 48.00 & 66.67 & $\mathrm{~F}$ & IV & IV & V & IV-V & & $\mathrm{F}$ \\
\hline Chatham & 47.03 & 65.46 & $\mathrm{~F}$ & $\mathrm{~F}$ & IV & IV & IV-V & & \\
\hline Dalhousie & 48.06 & 66.38 & $\mathrm{~F}$ & III-IV & V-VI & $\mathrm{V}-\mathrm{VI}$ & & & \\
\hline Edmundston & 47.37 & 68.33 & & & & IV & $\mathrm{F}$ & & \\
\hline Fredericton & 45.97 & 66.65 & IV & V-VI & IV & IV-V & V-VI & IV & IV \\
\hline Grand Falls & 46.92 & 67.75 & & & IV & V-VI & $\mathrm{F}$ & & \\
\hline Hartland & 46.30 & 67.53 & & & IV & & $\mathrm{F}$ & & $\mathrm{F}$ \\
\hline Moncton & 46.10 & 64.78 & & $\mathrm{~F}$ & IV & IV & V & & $\mathrm{F}$ \\
\hline Newcastle & 47.01 & 65.57 & & IV-V & $\mathrm{F}$ & IV-V & IV-V & & \\
\hline Sackville & 45.89 & 64.37 & & III & & IV & V & & \\
\hline Saint John & 45.27 & 66.05 & IV & IV & IV-V & IV & V & IV & IV \\
\hline Shediac & 46.22 & 64.55 & & $\mathrm{~F}$ & & $\mathrm{~F}$ & III-IV & & \\
\hline St. Andrews & 45.08 & 67.05 & IV & IV & & F & $\mathrm{F}$ & & \\
\hline St. George & 45.13 & 66.83 & & IV-V & & & F & & \\
\hline St. Stephen & 45.19 & 67.28 & & IV & $\mathrm{F}$ & F & IV-V & IV & \\
\hline Sussex & 45.73 & 65.52 & & IV & & IV & & & \\
\hline Woodstock & 46.14 & 67.58 & & $\mathrm{~F}$ & IV & IV-V & & IV & III \\
\hline
\end{tabular}

Notes: Modified Mercalli intensity values assigned by Burke (2009). F = earthquake was felt. 

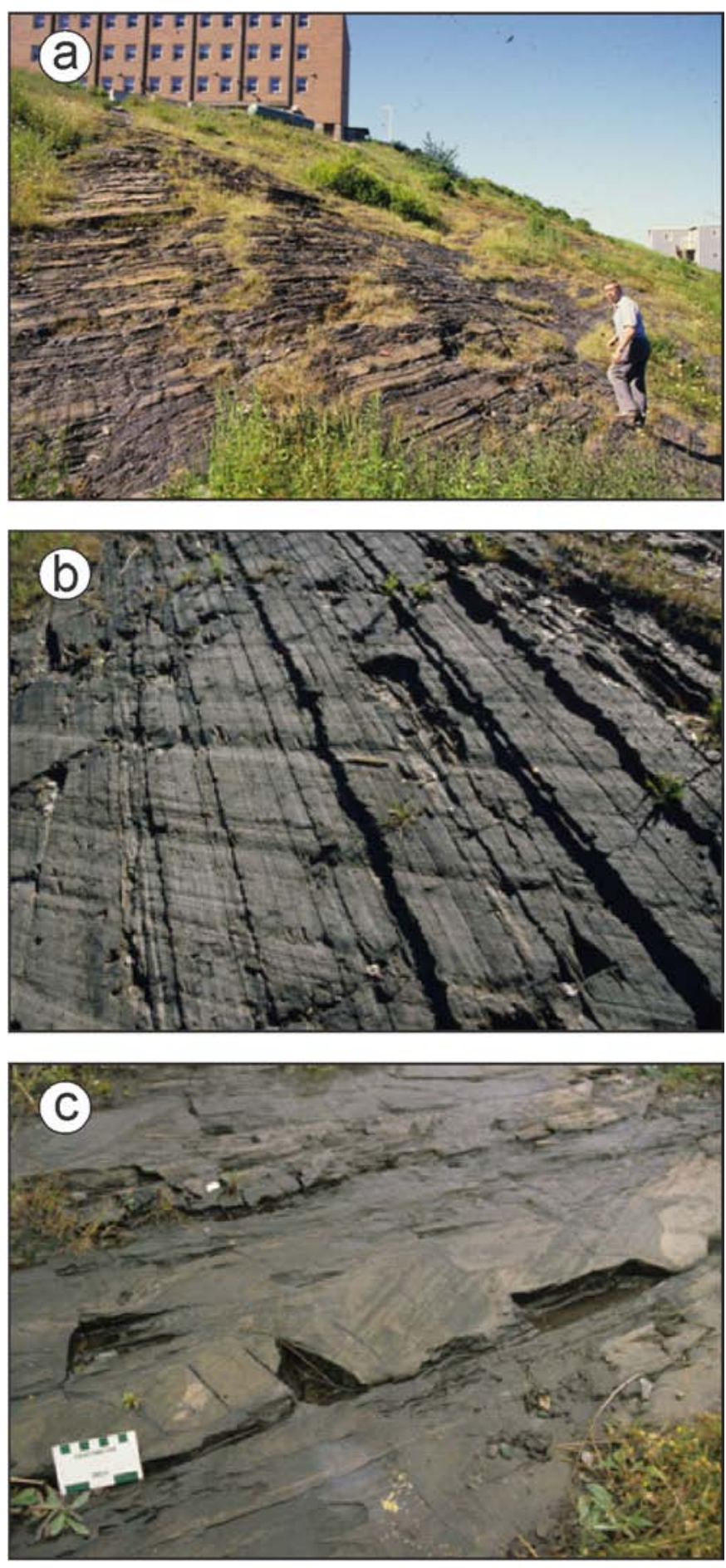

Fig. 6. Outcropping slaty bedrock at Rock Street, Saint John (a), showing groves and striae crossing sharp-edged small reverse faults $(b)$, and glacially rounded edges on some layers (c) from Broster and Burke (1990). Glacial movement has been towards the building at top of photo in (a), from left to right in (b), and from bottom left to top right $(c)$. Note the pen in centre of photo $(b)$ for scale.
The deformation was examined by Broster et al. (1993) and consisted of a variety of structures, including sand expulsions, areas of fluidization, upward-folded, stretched and resedimented layers, fractures, and displaced blocks of layered sediment (Figs. 7a-d). The tops of the deformation structures were disturbed by ploughing that occurred after the mid-1800s (Fig. $7 \mathrm{~d})$. In the undeformed layrs, projectile points and lead shot (from just below the ploughed zone) delineated a sequence of habitation extending beyond the last 2500 years, as supported by carbon dating. However, in one deformation structure, the clustering of heavy objects lower in the structure and lighter objects higher in the structure, suggested separation by density differences during liquefaction and loss of strength, rather than by anthropogenic reburial. Similar dyke-like sand 'boils' or 'volcanoes' have been reported near the location of other earthquake events (e.g., Tuttle and Seeber 1991; Bolt 1995; Tuttle 2001).

From examination of newspaper reports for the area and considering the unfrozen state of the ground when disturbed, Broster et al. (1993) deduced that the disturbance was likely the result of the October 22,1869 earthquake in the Miramichi region. These results support the re-assignment of the epicentre for the 1869 event from the Bay of Fundy to the Central Highlands.

\section{Site Specific Factors}

While ground-related effects of historical earthquakes have been noted at many locations across the province, communities sited on thick deposits of unconsolidated sediments are most prone to ground disturbance such as amplified ground motion, subsidence and liquefaction.

These are sites that represent lake plains, marine plains, flood plains and valleys and include larger urban centres such as Fredericton, Miramichi City (formerly Newcastle and Chatham), Moncton, and parts of Saint John, as well as several other smaller communities (see Tables 2, 4).

The sediments underlying Fredericton are typical of the deposits for the larger valleys that were estuaries during deglaciation of the province. These valleys consist of bedrock overlain by till and ice-contact sand and gravel, overlain and deglacial stratified sediments consisting of a waterlain clay-silt unit, underlain and overlain by units of fine to coarse sand and the sequence capped by post-glacial alluvium. The lower sandrich unit serves as a supply aquifer that is semi-confined and in part, separated from the uppermost alluvial sandy unit by the clay-silt unit. The deglacial sediments were deposited as glaciers retreated up valleys, forming large estuaries and glacial lakes prior to isostatic rebound to current elevations.

From drilling at the confluence of Grand Lake and the Saint John River (Dickinson 2008), and in the Saint John River valley, just north of Fredericton (Watson 1970), it has been demonstrated that more than $60 \mathrm{~m}$ of stratified sand, silt and clay have been deposited in places, with approximately $42 \mathrm{~m}$ underlying the urban centre of Fredericton (Daigle 2005). A review of geotechnical investigations at Fredericton by Broster 

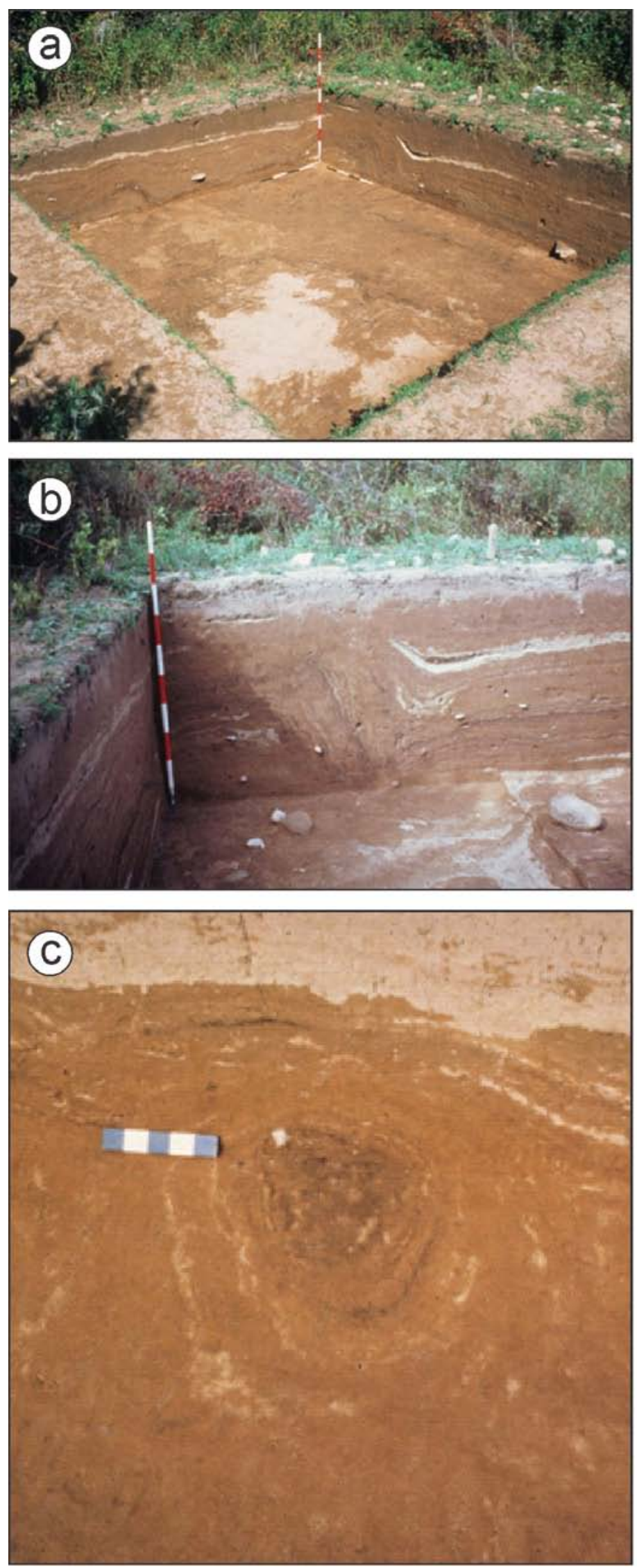

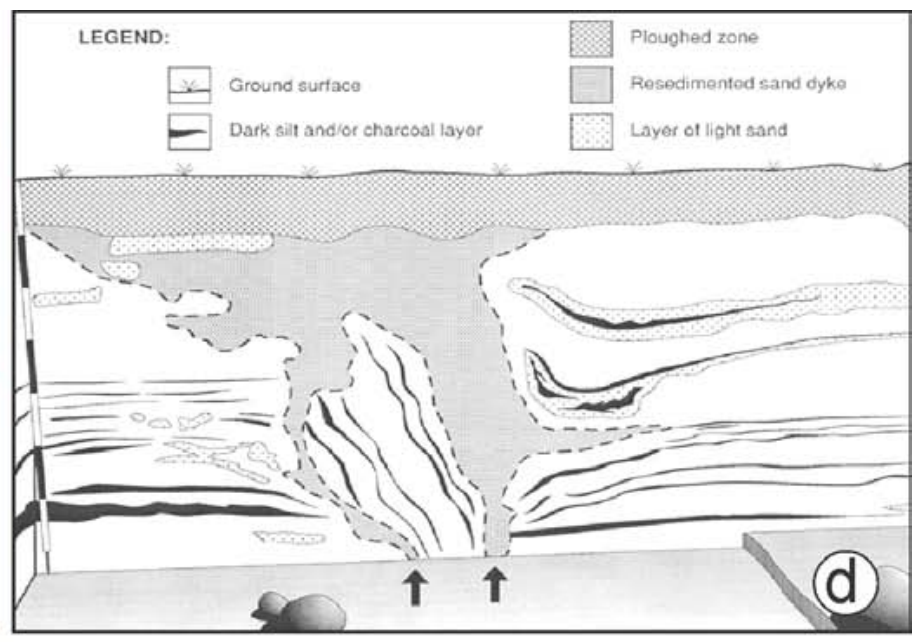

Fig. 7. Photo (a) looking northwest showing floor and excavated pit floor at Oxbow site, note exposed sand blow of white sand in floor at bottom of picture. Close-up (b) of deformation in north wall and cross-section view, (c) of vertical dyke-like structure. Sketch (d) of deformation in (a) and (b). Sketch and photos from Broster et al. (1993).

(1998) discusses zones within the clay-silt unit that exhibit inherent stiffness, but can change to a low-strength gelatinous state when only slightly disturbed. Analysis by Daigle (2005) of core samples collected from drilling through a $16 \mathrm{~m}$ thick part of the clay-silt unit between depths of $6 \mathrm{~m}$ and $22 \mathrm{~m}$ below surface, found liquidity index ranges of 0.57 to 1.73 . Material with values $>1.0$ can become viscous if disturbed (Das 2005) resulting in re-sedimentation and possible differential settlement under some structures.

Values for shear wave (Vs) seismic interval velocities were obtained by Nadeau (2005) and Nadeau et al. (2004) from three boreholes drilled through the Fredericton sequence of sediments. Shear wave velocities of $100-300 \mathrm{~m} / \mathrm{s}$ were observed for the uppermost $20-30 \mathrm{~m}$ of the alluvial sand and the middle clay-silt units. Amplification of ground motion would be expected at sites overlying these low shear wave velocity zones and may explain the larger shaking effects of earthquakes in the downtown area of Fredericton.

Minor alteration of springs, rivers and water tables occurs as a result of earthquakes, as mentioned previously, although few effects are permanent. Some wells were reported to have gone dry on Dorchester Island, close to Sackville, as a result of the 1817 earthquake. (see Fig. 2 for locations), whereas in the Miramichi region, new springs appeared and others diminished in flow at the time of the October 20, 1869 earthquake.

Movements within the marine sediments, or along steep rock slopes, such as those that border the Bay of Fundy, should be expected during seismic events, although few have been reported. Earthquake-induced mass movements accompanying ground motion of steep slopes have only been reported oc- 
casionally in the province. A rock fall occurred on Pickwaiket Mountain, close to Hampton, at the time of the February 8th, 1855 earthquake. At the time of the September 30th, 1937 earthquakes, several rock slides were reported on Sugarloaf Mountain, near Campbellton (Burke 2009).

Ruitenberg and McCutcheon (1978) report that on November 26, 1977 a slump occurred in a wedge of marine clay, silt and minor sand overlying fractured bedrock, forming a slope along the south shore of Lorneville Cove, $12 \mathrm{~km}$ west of Saint John (Fig. 2), that may have been triggered by seismic activity. A weak tremor was reported by a local resident to have occurred around the time of the slump, although an earthquake was not detected by seismometers. The slump occurred after heavy rainfall and site factors such as saturated sediments with low shear strength, a steep slope, and continuous erosion of the toe of the slope by tidal currents, likely contributed to the failure.

No other reported instances of earthquake-triggered movements in the landslide prone areas of the province have been found. It is possible that other landslips were triggered by earthquakes in the past but went unnoticed because they were not close to populated areas.

On November 18, 1929, the magnitude 7.2 earthquake on the Grand Banks produced a tsunami, primarily a result of a landslide at the continental slope (Ruffman 1996, 2005). Although high tides were reported at Chatham and Moncton, these were most likely caused by the storm raging over the province at the time of the earthquake (Burke and Slauenwhite 1987). An extensive review of coastal flooding in Atlantic Canada is presented by Ruffman (1996), but no reports of flooding in New Brunswick as a result of seismic-related wave action were documented. This is likely due to the geographic location of the province, shielded in part from waves generated in the Atlantic by Nova Scotia to the southeast and Prince Edward Island to the east. Poirier (1985) examined the wave patterns that would have been generated by a tsunami from the November 18, 1755 magnitude 7 earthquake, off the coast of Cape Ann, Massachusetts, to the south of the Bay of Fundy. He concluded that they would likely not have presented a threat to New Brunswick's southern coast, because of the refraction of waves to the coast of southwestern Maine, caused by the shallowing of the water column at the approaches to the Bay of Fundy.

The above results are limited in scope and do not consider the possibility of local tsunamis being caused by offshore earthquakes or a bolide falling within the Bay of Fundy, or along the northern and eastern coasts of the province. Ruffman (1991) proposed the possibility of an earthquake source zone off the coast of southwest Nova Scotia. This idea appears to have been based mainly on the transfer of the epicentre of a January 1 , 1883 earthquake from the Passamaquoddy Bay region to off the coast of Nova Scotia, although he also cites other Nova Scotia events in 1813 and 1848 as being possibly tsunamigenic. Newspaper reports discovered by Burke (2009) support the relocation of the 1883 earthquake to offshore Nova Scotia, but no reports of local tsunamis or flooding were found for communities along the shores of the Bay of Fundy. However, the following report was found for a Sept 26, 1852 event in the
Baie des Chaleurs in the October 2, 1852 issue of the Gleaner and Northumberland, Kent, Gloucester and Restigouche Commercial and Agricultural Journal.

COUNTY OF RESTIGOUCHE.

A correspondent writes us to say, that on Sunday week, about half past four in the afternoon, there was a smart shock of an Earthquake felt in many parts of the County; and at Dalhousie it was accompanied by a subterranean sound, after which three or four great waves of the sea came in. Our correspondent adds-"Having felt in the West Indies so many of these things, I knew what the sound was at once, before the shock."

This report indicates the possibility of a tsunamigenic earthquake-source off the northern coast of New Brunswick.

Seiches could possibly occur on Grand Lake and other small lakes within the province. However, no reports of seiches in New Brunswick were found in the study of historical earthquakes, although the waters of Spruce Lake, close to Saint John were reported as being discoloured at the time of the October 22, 1869 earthquake (Burke 2009).

\section{CONCLUSIONS}

New Brunswick has been spared many effects of earthquakes that are common to other parts of the world. Potential hazards to the public include; floods from embankment failure, alteration to flow of rivers and springs, mass movements, tsunami along coasts, seiches in lakes, and ground disturbance such as vibration and differential settlement from liquefaction and dewatering. Building vibration is often greatest for taller buildings and particularly for structures sited overlying thick deposits of sediment, and causes collapse of walls or fall of architectural features.

No location in New Brunswick is completely free of earthquake hazard. The province experiences occasional moderate earthquakes in the magnitude 5 to 6 range, with the areas of most frequent event recurrence being in the Central Highlands, Passamaquoddy Bay and the Moncton sub-zones. These earthquakes have resulted in minor damage to buildings and some effects on natural features. Major historical earthquakes with epicentres outside of the province have resulted in felt intensity levels up to VI at some locations in New Brunswick. Government data banks offer a reasonable but incomplete source for New Brunswick earthquake data due to limited inclusion of seismic events, possible inclusion of occasional non-seismic events, mistaken location of epicentres for some events, and the sparse number of maintained seismometers in the province. Assessment difficulties due to the limitations of the instrument event-record have been assisted by study of historical records and paleoseismic research. Recent examination of historical documents and paleoseismic research indicate that revisions are necessary for some of the listed earthquakes in the NEDB.

Results presented here demonstrate that effective and ac- 
curate earthquake hazard assessment can only be achieved through considering historical and paleoseismic evidence for recurrence of moderate local earthquakes, as well as the examination of specific site conditions that may be affected by local or larger regional events. Because of the variable terrain slopes and sediment type and thicknesses within each city area, microzonation studies are needed to identify areas prone to earthquake-induced hazards such as liquefaction, mass-movements and hydrological change. We suggest that further paleoseismic studies are warranted and evidence should be sought for prehistoric tsunami events.

\section{ACKNOWLEDGEMENTS}

We wish to thank M. Lamontagne and an anonymous reader for reviews of an earlier manuscript and suggestions. Figures 6a-c were published previously in Atlantic Geology and permission to publish figures $7 \mathrm{a}-\mathrm{c}$ was granted by Elsevier. Research funding to Broster from the New Brunswick Department of Natural Resources, Geological Survey Branch is gratefully acknowledged.

\section{REFERENCES}

Basham, P.W., and Adams, J. 1984. The Miramichi, New Brunswick earthquakes: near surface thrust faulting in the northern Appalachians. Geoscience Canada, 11, pp. 115-121.

Basham, P.W., and Kind, R. 1986. GRF broad-band array analysis of the 1982 Miramichi, New Brunswick earthquake sequence. Journal of Geophysics, 60, pp. 120-128.

Bent, A.L. 1992. A re-examination of the 1925 Charlevoix earthquake. Bulleting of Seismological Society of America, 82, pp. 2097-2113.

Bent, A.L. 1995. A complex double couple source mechanism for the MS 7.2 1929 Grand Banks earthquake. Bulletin of Seismological Society of America, 85, pp. 1003-1020.

Bolt, B.A. 1995. Earthquakes - Newly Revised and Expanded. W.H. Freeman and Company, New York, 331 p.

Broster, B.E. 1991. Glacitectonic deformation in sediment and bedrock: Hat Creek, British Columbia. Géographie physique et Quaternaire, 45, pp. 5-20.

Broster, B.E. 1998. Aspects of engineering geology at Fredericton, New Brunswick. In Urban Geology of Canadian Cities. Edited by P.F. Karrow and O.L. White. Geological Association of Canada Special Paper 42, pp. 401-408.

Broster, B.E., and Burke, K.B.S.1990. Glacigenic postglacial faulting at Saint John, New Brunswick. Atlantic Geology, 26, pp. 125-138.

Broster, B.E., and MacDougall, D.A. 1997. Paleoseismic implications of fluid-escape structures in raised deltas at Lower Five Islands - Economy Point, Nova Scotia. Atlantic Geology, 33, pp. 1-10.

Broster,B.E.,Allen,P., andBurke,K.B.S.1993.Amultidisciplinary assessment of postglacial seismic disturbance: Miramichi area, New Brunswick, Canada. Quaternary International, 20, pp. 153-161. doi:10.1016/1040-6182(93)90044-G

Burke, K.B.S. 1984. Earthquake activity in the Maritime Provinces, Geoscience Canada, 11, pp. 16-22.

Burke, K.B.S. 2004. Historical seismicity in the Central Highlands, Passamaquoddy Bay, and Moncton regions of New Brunswick. Seismological Research Letters, 7, pp. 419-431. doi:10.1785/gssrl.75.3.419

Burke, K.B.S. 2009. Historical earthquakes felt in New Brunswick (1764, 1811-1960). Sadler Geophysical and Administrative Services Ltd., 747p.

Burke, K.B.S., and Slauenwhite, S. 1987. Felt Effects of the 1929 Grand Banks Earthquake in New Brunswick. Contract Report for Canada Department of Energy, Mines and Resources, Geological Survey of Canada, Geophysics Division, Ottawa, Ontario, Canada Department of Supply and Services, Contract File No. 23233-6-3421/01-ST, 56 p.

Clague, J.J., Naesgaard, E., and Sy, A. 1992. Liquefaction features on the Fraser Delta: evidence for prehistoric earthquakes? Canadian Journal of Earth Sciences, 29, pp. 1734-1745.

Daigle, A.E. 2005. Stratigraphy and three-dimensional architecture of surficial sediments at Fredericton, New Brunswick. Unpublished MSc thesis, University of New Brunswick, Fredericton, New Brunswick, Canada, 162 p.

Das, B.M. 2005. Fundamentals of Geotechnical Engineering. Nelson Division of Thompson Publishers, Toronto, $566 \mathrm{p}$.

Dickinson, P.J. 2008. Geomorphological processes and the development of the lower Saint John River human landscape. Unpublished Ph.D. thesis, University of New Brunswick, Fredericton, New Brunswick, Canada, 305p.

Doughty, M., Eyles, N., and Daurio, L. 2010. Ongoing Neotectonic activity in the Timiskaming- Kipawa area of Ontario and Quebec. Geoscience Canada, 37, pp 109-116.

Halchuk, S., Burke, K.B.S., and Adams, J. 2004. Note on the magnitude recurrence relationships for the Central Highlands, Passamaquoddy Bay and Moncton sub-zones of New Brunswick, Canada. Seismological Research Letters, 75, pp. 432-434. doi:10.1785/gssrl.75.3.432

Humphreys, W.J. 1922a. Seismological reports for July, 1922. In Monthly Weather Review, American Meteorological Society, $50,451 \mathrm{p}$.

Humphreys, W.J. 1922b. Seismological reports for September, 1922. In Monthly Weather Review, American Meteorological Society, 50, 513 p.

Lamontagne, M., Halchuck, S., Cassidy, J.F., and Rogers, G.C. 2007. Significant Canadian Earthquakes 1600-2006. Geological Survey of Canada Open File 5539, 32p.

Leblanc, G., and Burke, K.B.S. 1985. Re-evaluation of the 1817, 1855, 1869, and 1904 Maine-New Brunswick earthquakes. Earthquake Notes, 56, pp. 107-123.

Matthew, G.F. 1894. Movements of the Earth's crust at Saint John, New Brunswick in post-glacial times. Bulletin of the Natural History Society of New Brunswick, 12, pp. 34-42.

Nadeau, J-C. 2005. Geophysical imaging of a river valley aqui- 
fer, Unpublished MSc thesis, University of New Brunswick, Fredericton, New Brunswick, Canada, 141 p.

Nadeau, J.C., Butler, K.E., Hunter, J.A., Veillette, N., Douma, M., Burns, R.L., and Good, R.L. 2004. Reflection and downhole seismic studies of a glaciofluvial river valley aquifer. In Proceedings of 17th Annual Symposium on the Application of Geophysics to Engineering and Environmental Problems (SAGEEP 2004). Environmental and Engineering Geophysical Society, pp. 1408-1419.

Natural Resources of Canada 2010a. Earthquakes Canada, simplified seismic hazard map for Canada. Geological Survey of Canada. URL <http://earthquakescanada.nrcan.gc.ca/ hazard-alea/simphaz-eng.php>, July 2010.

Natural Resources of Canada 2010b. Earthquakes Canada, interpolate 2005 national building code of Canada seismic hazard values for your site. Geological Survey of Canada. $\mathrm{URL}<\underline{\text { http://earthquakescanada.nrcan.gc.ca/hazard-alea/ }}$ interpolat/index-eng.php $>$, July 2010.

Natural Resources of Canada 2010c. Earthquakes Canada, earthquake zones in Eastern Canada, Northern Appalachians seismic zone. URL <http://earthquakescanada.nrcan. gc.ca/zones/eastcan-eng.php\#NASZ>, July 2010.

Natural Resources Canada 2010d. Earthquakes Canada, Earthquake search (on-line Bulletin). Geological Survey of Canada. URL $<$ http://earthquakescanada.nrcan.gc.ca/stndon/ NEDB-BNDS/bull-eng.php $>$, July 2010.

Pernica G., and Maurenbrechen, A.H.P. 1982. Survey of building damage in New Brunswick caused by the 1982 New Brunswick earthquake. In Preliminary Report of the Miramichi, New Brunswick, Canada earthquake sequence of 1982. Edited by A.E. Stevens. Earth Physics Branch Open File Report 82-24, pp. 56-70.

Poirier, R. 1985. Tsunamis in the Atlantic Provinces. Unpublished Senior Undergraduate Report, University of New Brunswick, Fredericton, New Brunswick, Canada, 40p.

Rajendran, C.P. 2000. Using geological data for earthquake studies: a perspective from peninsular India. Current Science, 79, 1251-1258.

Rast, N., Burke, K. B. S., and Rast, D. 1979. The earthquakes of eastern Canada and their relationship to structure. Geoscience Canada, 6, pp. 173-179.

Reiter, L.R. 1990. Earthquake Hazard Analysis. Columbia University Press, New York, 254p.

Ruffman, A. 1991. The case for a seismic zone off southwest Nova Scotia in the Gulf of Maine or along the edge of the continental shelf/slope. In Workshop on Eastern Seismicity Source Zones for the 1995 Seismic Hazard Maps, Proceedings. Compiled by J. Adams. Geological Survey of Canada, Open File No. 2437, 356-370.

Ruffman, A. 1996. Tsunami runup mapping as an emergency preparedness planning tool: the 1929 tsunami in St. Lawrence, Newfoundland. Contract Report for Emergency Preparedness Canada, Office of the Senior Scientific Advisor, Ottawa, 1, 107p.
Ruffman, A. 2005. Comment on Tsunamis and Tsunami-like waves of the eastern United States by Patrica A. Lockridge, Lowell S. Whiteside, and James F. Lander with respect to the November 18, 1929 Earthquake and its tsunami. Science of Tsunami Hazards, 23, pp. 52-59.

Ruitenberg, A., and McCutcheon, S.R. 1978. Engineering geology of the Lorneville Cove Landslide. New Brunswick Department of Natural Resources, Open File Report No. 78-7, 7p.

Smith, W.E.T. 1962. Earthquakes of eastern Canada and adjacent areas 1534-1927. Publication of the Dominion Observatory, vol. XXVI, No 5, pp. 271-301.

Smith, W.E.T. 1966. Earthquakes of eastern Canada and adjacent areas 1928-1959. Publication of the Dominion Observatory, vol. XXXII, No 3, pp. 87-121.

Tanoli, S.K., and Pickerill, R.K. 1988. Lithostratigraphy of the Cambrian-Lower Ordovician Saint John Group, southern New Brunswick. Canadian Journal of Earth Sciences, 25, pp. 669-690.

Tuttle, M.P. 2001. The use of liquefaction features in paleoseismology: Lessons learned in the New Madrid seismic zone, central United States. Journal of Seismology, 5, pp. 361-380. doi:10.1023/A:1011423525258

Tuttle M.P., Lafferty, R.H., Guccione, M.J., Schweig, E.S., Lopinot, N., Cande, R.F., Dyer-Williams, K., and Haynes, M. 1996. Use of archaeology to date liquefaction features and seismic events in New Madrid seiamic zone, Central United States. Geoarchaeology, 11, 451-480. doi:10.1002/(SICI)15206548(199612)11:6<451::AID-GEA1>3.0.CO;2-5

Tuttle, M.P., and Seeber, L. 1991. Historic and prehistoric earthquake-induced liquefaction in Newbury, Massachusetts. Geology, 19, pp. 594-597. doi:10.1130/00917613(1991)019<0594:HAPEIL>2.3.CO;2

US Geological Survey 2010. Earthquake hazards program. US Department of the Interior. URL <http://earthquake.usgs. gov/earthquakes/eqarchives/epic/epic_rect.php>, July 2010.

Watson, R.G. 1970. Foundation conditions - The Mactaquac rockfill dam, World Dams Today' 70, The Japan Dam Association, Tokyo, pp. 310-315.

Weichert D.H. 1980. Estimation of the earthquake recurrence parameters for unequal observation periods for different magnitudes. Bulletin of Seismological Society of America, 70, pp. 337-1346.

Wetmiller, R.J., Adams, J., Anglin, F.M., Hasegawa, H.S., and Stevens, A.E. 1984. Aftershock sequences of the 1982 Miramichi, New Brunswick, earthquakes. Bulletin of Seismological Society of America, 74, pp. 621-653.

Wheeler, R., and Johnston, A.C. 1992. Geologic implications of earthquake source parameters in central and eastern North America. Seismological Research Letters, 63, pp. 491-514.

Editorial responsibilty Daniel J. Utting 